Mihaela M. Malešević*

УДК

Doktorand

811.111'367.625

Univerzitet u Beogradu

Filološki fakultet

ДОИ

https://doi.org/10.18485/analiff.2017.29.1.10

\title{
PREVOĐENJE GLAGOLA SA METAFORIČKOM DOPUNOM U ENGLESKOM JEZIKU KAO STRANOM
}

\begin{abstract}
Cilj rada je analiza uspješnosti doslovnih prevoda odabranih glagola sa metaforičkom dopunom i prevoda takvih metaforičkih konstrukcija koji se baziraju na upotrebi rečeničnog konteksta, u jeziku medicinske struke.

U teorijskom dijelu rada iznosimo pregled konceptualnih metafora kao i probleme koji se mogu javiti prilikom prevođenja figurativnog jezika, dok ćemo u empirijskom dijelu predstaviti kako su studenti, koji se prvi put prema nastavnom programu susreću sa ovakvim konstrukcijama, preveli date glagole sa metaforičkom dopunom te da li su se i u kojoj mjeri oslanjali na kontekst rečenice. Analiza se zasniva na prevodu deset metafora zdravlja i bolesti izdvojenih iz rječnika sinonima Thesaurus of Traditional English Metaphors i naučnog članka "Conceptual Metaphor in Everyday Language".
\end{abstract}

Ključne riječi: engleski jezik, jezik medicinske struke, kontekst i prevođenje, metaforička dopuna

\section{Uvod}

Prema tradicionalnom viđenju, metaforu bismo definisali kao stilsko izražajno sredstvo ili retoričku figuru kojom se jedna stvar uspoređuje s drugom. Tako Zoltan Kevečeš (Kövecses) navodi da je ona prvobitno smatrana svojstvom riječi, odnosno lingvističkim fenomenom a da se tek kasnije može koristiti za umjetničke svrhe. Metafora je svjesna i namjerna nedoslovna upotreba riječi, a samo veliki pjesnici mogu njome potpuno ovladati (Kövecses, 2010: 11). Međutim, čini se da su Lejkof i Džonson promijenili takvo viđenje metafora, te karakterišu metaforu kao univerzalno obilježje jezika koje je ,sveprisutno u svakodnevnom životu,

Kontakt: mihaela.gojkovic@mail.com 
ne samo u jeziku nego i mišljenju i djelovanju“ (Lakoff i Johnsen, 2003: 3). Oni smatraju da je svakodnevni život protkan metaforičkim izrazima te da je metaforizacija temeljna za razumijevanje jezika, dok za metaforu kao kognitivni mehanizam lingvisti koriste termin konceptualna metafora. Konceptualna metafora predstavlja preslikavanje iz poznatog, konkretnog domena $u$ apstraktniji, ciljni domen.

U radu stavljamo naglasak na analizu prevoda glagola sa orijentacijskim partikulama i metaforičkom dopunom. Empirijsku osnovu rada čine prevodi deset metaforičkih konstrukcija sa orijentacijskim parametrima izdvojenih iz rječnika sinonima Thesaurus of Traditional English Metaphors (Wilkinson, 2002) i naučnog članka "Conceptual Metaphor in Everyday Language” (Lakoff \& Johnsen, 1980). Nakon kratkog teorijskog prikaza konceptualnih metafora i uloge konteksta u prevođenju, predstavićemo kako su studenti preveli date glagole sa metaforičkom dopunom.

U zaključku navodimo da su mnogi glagoli sa metaforičkom dopunom prevodivi za studente ali kada se određen izraz identifikuje, naredni problem sastoji se od njegovog dekodiranja. Rječnici nisu uvijek pouzdane alatke za rješavanje te vrste problema te se studenti često oslanjaju na upotrebu maternjeg jezika, što ne predstavlja jednu od najkorisnijih strategija pri prevođenju metaforičkog vokabulara.

\section{Konceptualna metafora}

Teorija Lejkofa i Džonsona predstavlja prekretnicu u jezičkom istraživanju i analizi metafora. Oni zapažaju da su metafore preovlađujuće u svakodnevnom životu i da je naš pojmovni aparat suštinski metaforičan. Od izuzetnog značaja je činjenica da se metafora više ne vidi kao stilska figura već se posmatra kao jedna od najosnovnijih pojava zbog koje mišljenje i jezik jesu isključivo metaforičke prirode.

Konceptualna je metafora jedan od kognitivnih procesa konstruisanja značenja na temelju kojeg povezujemo dvije konceptualne domene: izvornu domenu (engl. source domain), u kojoj se odvija važno metaforičko rasuđivanje i koja obezbjeđuje izvorne pojmove koji se koriste u tom rasuđivanju, i ciljnu domenu (engl. target domain) koja se sastoji od neposredne teme (Lakoff i Johnsen, 2003: 265). Izvorni domen često je povezan sa fizičkim iskustvom, samim tim je i konkretniji, iskustveno bliži, dok je ciljni domen 
apstraktniji, pa su konceptualne metafore osnovno sredstvo za razumijevanje apstraktnih iskustava (Klikovac, 2004: 14). Povezivanje određenog izvornog domena sa određenim ciljnim domenom motivisano je iskustvom. Neke od tipičnih izvornih domena koje Kevečeš navodi su ljudsko tijelo, zdravlje i bolest, životinje, biljke, dok su neke od tipičnih ciljnih domena emocije, želja, mišljenje, vjera, život (Kövecses, 2002 prema Klikovac, 2004: 17-18). D. Klikovac smatra da brojnost izvornih i ciljnih domena samo pokazuje koliko su metafore važne za snalaženje u apstraktnim oblastima iskustva te da su svi naši najvažniji apstraktni pojmovi, na neki način, definisani pomoću metafora (Klikovac, 2004: 19). Sve metafore se realizuju kroz metaforičke jezičke izraze (eng. metaphorical linguistic expressions), koje Kevečeš (Kövecses, 2002: 4) definiše kao riječi ili druge jezičke izraze koji potiču iz jezika ili terminologije konkretnijeg pojmovnog domena, tj. iz izvornog domena. Lejkof i Džonson smatraju kako je konceptualna metafora sredstvo koje omogućava razumijevanje složenih domena pomoću onih jednostavnijih koje su bliže našem iskustvu (Lakoff i Johnsen, 2004: 75-83).

Usljed prostornih ograničenja, nećemo navoditi sve teorije i podjele vezane uz konceptualnu metaforu, nego ćemo samo navesti podjelu prema Lejkofu i Džonsonu (Lakoff i Johnsen, 2003). Navedeni autori razlikuju strukturne, orijentacijske i ontološke metafore. Kod strukturnih metafora jedan se koncept strukturira pomoću drugog, a primjeri takvih metafora su život je putovanje ili vrijeme je novac. Kod orijentacijskih se metafora, odnosno kod glagola sa orijentacijskom metaforičkom dopunom, cijeli sistem pojmova organizuje u odnosu na drugi, kao u primjerima zdravlje $i$ život su gore, bolest i smrt su dole. Orijentacijske metafore utemeljene su na našem fizičkom i kulturnom iskustvu. Iskustva s konkretnim fizičkim predmetima stvaraju podlogu za tvorbu ontoloških metafora. Kod ontoloških metafora događaji, aktivnosti i emocije postaju entiteti ili fizičke stvari, što uglavnom nastaje konkretizacijom apstraktnoga. Lejkof i Džonson kao ontološke metafore navode metafore poput um je omeđeni prostor. One omogućavaju uočavanje strukture tamo gdje je gotovo ili uopšte nema.

Lejkof i Džonson smatraju da je metafora ,,prirodni fenomen“. Prema njima, konceptualna metafora je prirodni dio ljudske misli, a lingvistička metafora je prirodan dio ljudskog jezika. Osim toga, koje metafore imamo i šta one znače zavisi od prirode našeg tijela, naše interakcije u fizičkom okruženju te naših društvenih i kulturnih praksi. Svako pitanje o prirodi konceptualne metafore i njezine uloge u misli i jeziku je empirijsko pitanje (Lakoff i Johnsen, 2003: 247). 


\subsection{Glagoli sa metaforičkom dopunom zdravlja i bolesti}

Iskustva zdravlja i bolesti prožimaju svakodnevni ljudski život, ali kao što je to slučaj s većinom naših temeljnih iskustava, pojmovi kojima ih pokušavamo objasniti nisu uvijek jasno određeni. Pojam zdravlja može biti teže objasniti možda zato što ga u svakodnevnom životu rijetko koristimo kako bismo opisali naša iskustva. Zdravlja postajemo svjesni uglavnom onda kada iskušavamo ono što nazivamo bolest.

Kako bi uvidio na koji način metafore oblikuju pojmove zdravlja i bolesti i u kolikoj mjeri, Babel (2012) je pokušao da ispita njihove izvore unutar kulturnog konteksta u kojima su nastali, te da razmotri njihov uticaj, a u obzir je uzeo dvije metafore koje preovlađuju i u jezičkoj upotrebi i u ljekarskoj praksi u kontekstu zapadne tradicije - tijelo kao stroj i medicina kao rat. Babel navodi da se u ljekarskoj praksi metafora odražava prije svega u doživljavanju ljekara, kako od strane pacijenata tako i samih ljekara, kao inženjera ili mehaničara, tj. posjednika autoritativnog znanja o funkcionisanju kompleksnog stroja i upotrebi tehnologije za dijagnozu i liječenje. Ljekar preuzima aktivnu ulogu u zadatku pronalaska uzroka bolesti i odgovarajućih tretmana za povratak zdravlja. S druge strane, pacijenti su stavljeni u pasivan položaj te postaju objektima istraživanja - tijela - strojevi (Babel, 2012: 127).

Glagolske orijentacijske metaforičke dopune potiču iz naše prostorne orijentacije, a izvorni domeni su pojmovi poput gore-dole, unutra-spolja, naprijed-nazad, duboko-plitko, centralno-periferno itd. (Klikovac, 2004: 23). Lejkof i Džonson (2003) navode da su takve metafore sreća je gore-tuga je dole, dobro je gore-loše je dole. Klikovac (2004: 23) ih ilustruje primjerima kao što su bio je na sedmom nebu, lebdeo je od sreće, to mu je podiglo raspoloženje, prošle godine smo bili na vrhuncu ali od tada padamo. Prema ovim primjerima, možemo zaključiti da je orijentacija prema, gore“ povezana s pozitivnim, dok je orijentacija ka „dole“ u kombinaciji s negativnim. Klikovac smatra da je zanimljivo pomenuti načine na koje se orijentacijske metafore zasnovane na pojmu vertikalnosti manifestuju vanjezički. Jedan od primjera koji se navodi je metaforičko razumijevanje domena vrijednosti. Za proizvod se kaže da je visokog kvaliteta, za nekoga kažemo da se uspeo na politički vrh, a sportistu koji je osvojio prvo mjesto na nekom takmičenju penjemo na najviše mjesto na pobjedničkom postolju (Rasulić, 2002 prema Klikovac, 2004: 38).

Ukoliko govorimo isključivo o orijentacijskim metaforama zdravlja i bolesti, ili generalno o metaforama zdravlja i bolesti, čini se da je bitno po- 
menuti Susan Sontag koja u knjizi Bolest kao metafora iznosi tezu da bolest treba lišiti metafora, odnosno ,da je najbolji stav prema bolesti (i najzdraviji način bolovanja) svođenje metafora na minimum, odupiranje metaforičkom načinu mišljenja“" (Sontag, 1978: 3). Sontag na temelju istorijskih i literarnih izvora razmatra niz kulturnih mitova i metafora koje se vežu uz rak. Zbog straha i srama pacijenti odugovlače s traženjem medicinske pomoći, te je to osnovni razlog njenog stava da metafore bolesti mogu ubijati i da bi ih se trebalo u potpunosti riješiti. Primjeri takvih „negativnih“ metafora su a cell is a living entity that commits suicide, cancer is a war, fighting against your own body for your life, cancer patients are ill equipped.

S druge strane, Babel (2012) citira Barbaru Klou (Clow) koja je na temelju istraživanja javnog i privatnog diskursa o raku u prvoj polovini 20. vijeka ukazala na činjenicu da, suprotno Sontaginom uvjerenju, stav da je rak sramotna bolest o kojoj se šuti nije bio toliko prevladavajući. Ona zamjera pretjeranoj generalizaciji Sontaginog zaključka da sve bolesti treba lišiti metafora na temelju nekoliko negativnih posljedica metafora jedne bolesti (Clow, 2001 prema Babel, 2012: 136). Budući da je razumijevanje iskustva bolesti neodvojivo od ličnih, društvenih i kulturnih metaforički strukturiranih uvjerenja, uklanjanje metafora ${ }^{1}$ značajno bi smanjilo mogućnost izražavanja pacijenata o kompleksnim iskustvima bolesti. Tako, na primjer, u radu "Metaphor and illness experience: A comparative analysis of metaphors in male and female cancer patient narratives" (Huijbrechts, 2016) možemo vidjeti konkretne primjere upotrebe pozitivnih i negativnih metafora kod muških i ženskih pacijenta oboljelih od raka. Neki od primjera upotrebe metafora koje su svrstane u grupu "negativnih i neohrabrujućih" su fighting the battle in the trenches of our own bodies, it is hard to lead when waging war against cancer, faced with a disease that could kill me, discovered a lump, dok su neki primjeri metafora koje su okarakterisane kao ,pozitivne i ohrabrujuće” kod pacijena oboljelih od raka chemo was going to give many more future birthdays, flu bug has moved out, perhaps moving toward a peak, I have gone through the first "valley of tears" (Huijbrechts, 2016: 107-116).

Bez obzira na to da li se metaforički vokabular u jeziku medicinske struke koristi kao pozitivan ili negativan, njegova upotreba je svakako neizbježna prilikom ukazivanja na negativne posljedice, naglašavanja i/ili skrivanja određenih aspekata pojma bolesti.

1 Ukoliko bi to uopšte bilo moguće. 


\subsection{Glagoli sa metaforičkom dopunom i metafore u prevodu}

Kao sto je jezik živ i stalno se mijenja, tako i metafore doživljavaju svoje promjene, ,umiru“ ili se ,rađaju“, mijenjaju značenje ili dobijaju dodatna značenja. Da bismo ih razumjeli nije dovoljno samo poznavati riječi i gramatiku, nego je često potrebno shvatiti i kulturnu podlogu. S obzirom na to je da je metaforičko izražavanje sastavni dio svake komunikacije, te da je prisutnost metafora više nego očigledna i u stručnim tekstovima, neophodno je shvatiti važnost metaforičnosti kako bismo tekstove mogli pravilno tumačiti, a time i prevoditi.

U literaturi možemo naći mnoštvo faktora koji mogu imati uticaja na prevođenje (i prevodivost) metaforičkog vokabulara. Tako, na primjer, Fernandez smatra da su faktori koji utiču na mogućnost prenošenja metaforičkog značenja iz jednog jezika u drugi, između ostalih, kulturološke preference, komunikativna namjera, funkcionalna relevantnost, stepen informativnosti, tipologija metafora, ograničenja konteksta i kontekst, stepen kompatibilnosti pojmovnih i formalnih struktura dva konkretna jezika, dominantne sinhrone norme, stepen leksikalizacije metafore, kompetentnost prevodioca, razumljivost metafora, kognitivna uloga, itd. (Fernández, 2002: 206). Kad je riječ o prevodivosti metafora, odnosno o njihovoj sposobnosti prenošenja iz jednog jezika u drugi, prenos značenja iz izvornog teksta nije uvijek moguće zadržati u ciljnom tekstu, te se tako sam prenos značenja smatra jednim od najvećih problema u istraživanju prevođenja metaforičkog vokabulara.

Fernandez navodi sledeće pristupe prevođenju metafora u studijama prevođenja: (1) metafore su neprevodive (prevođenje date metafore će uvijek rezultirati različitom metaforom); (2) metafore su u potpunosti prevodive (prevođenje metafora nije ništa drugačije od bilo kojeg drugog prevođenja); (3) metafore su prevodive ali ispoljavaju znatan stepen neekvivalencije (metafora je specifičan problem prevođenja); i (4) srednji pristup, prema kome raspon mogućih prevoda zavisi od vrste teksta i od ad hoc faktora (Fernández, 2002: 206-207). Prema Fernandez, stepen leksikalizacije se koristi kao mjera prevodivosti, ali nema saglasnosti o tome koju vrstu metafora je najlakše prevesti. Schmidt (2014) navodi osnovna četiri načina na koja se može prevesti metafora:

1. korišćenje iste konceptualne metafore,

2. korišćenje različite konceptualne metafore, 
3. korišćenje nemetaforičke parafraze,

4. brisanje metafore (Schmidt, 2014: 95).

Pored navedenog, nemetaforički izraz se može prevesti i metaforičkim. Premda se prevođenje u savremenom dobu prepoznaje kao lingvistički i kulturni transfer (Schmidt, 2014: 95), prevođenje metafora je suština zadatka prevodilaca. Mnoge konceptualne metafore su univerzalne i pronalazimo ih u skoro svim jezicima, ali su neke kulturološki specifične i pojavljuju se samo u jednom jeziku.

Zdravko Radman u knjizi Metafore i mehanizmi mišljenja piše o problemu direktnog prevođenja, te navodi da doslovno (direktno) prevođenje predstavlja značajan dio metaforičkog kompleksa i vjerovatno najdelikatniji dio cijele problematike (Radman, 1995: 18). Radman se pita koliko je doslovno zaista doslovno, pokazujući da je izjednačavanje doslovnog s opažajnim osuđeno na neuspjeh jer ne otklanja mogućnost dvosmislenosti tumačenja. S druge strane, doslovno značenje nekog izraza ne može se pouzdano izvesti ni pomoću jednostavnog izdvajanja najosnovnijih leksičkih značenja jer je svakako potrebno raspolagati dodatnim ,pozadinskim pretpostavkama“" koje su neosporno ovisne o semantičkoj ili lingvističkoj kompetenciji korisnika jezika.

Jezička kompetencija ima vrlo važnu ulogu u određivanju doslovnog jer se doslovno značenje dobija izdvajanjem važnih semantičkih djelića iz konotacijskog i kontekstualnog polja izraza određenog našom jezičkom kompetencijom (Radman, 1995: 22). Pojam kompetencija podrazumijeva poznavanje predmeta, ali šta tačno znači poznavanje metaforičkog vokabulara ili samih metafora? Ako je osoba upoznata s jednim ili drugim od dva semantička područja koja čine metaforički izraz, postavlja se pitanje da li je to dovoljno da se smatra da ta osoba posjeduje kompetenciju prevođenja takve strukture? Prevodilac je možda ranije naišao na određeni metaforički izraz u maternjem jeziku (L1) ili u drugom, stranom, jeziku (L2), ali moglo bi se reći da je on upoznat s njim iz perspektive prevođenja samo onda kada je ostvarena veza između L1 i L2 metafore koja se odnosi na iste osnovne pojmove (Sjørup, 2013: 67). Prema Sjorup, kompetencija prevođenja metaforičkog izraza se može posmatrati kao sposobnost da se takva struktura poveže iz izvornog teksta i ciljnog teksta a ne samo kao sposobnost da se prevodilac osloni na ,preslikavanja“ iz prethodnih prevoda. Iz jednojezičke perspektive, osoba koja radi u određenom području će biti više upoznata s konvencionalnim metaforama u svom specifičnom 
području. Takva osoba može biti stručna u određenoj terminologiji, što bi moglo uključivati i metaforičke izraze u tom području ali to ne mora nužno značiti da se za istu osobu može reći da ima opštu kompetenciju prevođenja takvih struktura i da je time vještija u njihovom razumijevanju.

Andersen (2004) je definisala metaforičku kompetenciju u kontekstu prevođenja da bi istražila moguću povezanost između metaforičke kompetencije prevodioca i kompetencije prevođenja (Andersen, 2004: 5). Ona smatra da metaforička kompetencija prevodioca predstavlja aktivno svjesno poznavanje metafore u svim njenim dimenzijama, kao jezičke, pragmatičke i kognitivne jedinice, te tvrdi da, kako bi se metafora ispravno prevela, prevodilac mora biti svjestan različitih aspekata i teorija o konceptu metafore. Ona koristi izraz ,aktiviranje latentnog znanja“ te navodi da je ,prevodilac uvijek istovremeno u situaciji prijema i produkcije“" (Andersen, 2004: 57, prema Sjørup, 2013: 68). Autorka takođe smatra da će prevodilac često imati punu metaforičku kompetenciju u maternjem jeziku a ograničenu metaforičku kompetenciju u L2. ${ }^{2}$ Andersenova navodi da prevodioci teže ka relativno visokom nivou jezičke metaforičke kompetencije u smislu da su u stanju prepoznati metaforičke izraze kao metafore, dok su pragmatički i kognitivi nivoi metaforičke kompetencije često manje zadovoljavajući.

Biljana Radić-Bojanić je u svom radu istraživala način na koji studenti koriste strategije prevođenja metaforičkih izraza. Ona dolazi do zaključka da su u većini slučajeva studenti pokazali svijest o međujezičkim razlikama i sposobnost da uoče zamke koje se kriju u naizgled sličnim strukturama, pa, zahvaljujući i jezičkom znanju i iskustvu u upotrebi jezika, tim područjima ,koračaju polako uz razmišljanje i razmatranje međujezičkih razlika“" (Radić-Bojanić, 2014: 716). Autorka zaključuje da razvoj metaforičkog razmišljanja i pripadajuće strateške kompetencije kod studenata, kao i izgradnja njihovog samopouzdanja, mogu samo da doprinesu rastu njihove autonomije i povećanju sposobnosti da sa uspjehom uče (i nauče) strani jezik (Radić-Bojanić, 2014: 716-717).

Kako smo i naveli, mnogi faktori mogu uticati na prevod metaforičkih struktura, od vrste teksta koji se prevodi pa do funkcije koju treba da ispuni. U našem slučaju se studenti prvi put, prema nastavnom planu

2 Osim ako prevodilac nije svjestan svih aspekata koncepta metafore, slabija metaforička kompetencija u L2 će oslabiti njegovu prevodilačku kompetenciju. 
PREVOĐENJE GLAGOLA SA METAFORIČKOM DOPUNOM

U ENGLESKOM JEZIKU KAO STRANOM

i programu, susreću sa prevođenjem metaforičkog vokabulara iz domena medicinske terminologije. Prema tome, moguće je da su mnogi faktori uticali na izbor postupka prevođenja.

\section{Rečenični kontekst i (uspješno) prevođenje}

Kontekstualne informacije imaju razne uloge u mnogim procesima i potprocesima čitanja i prevođenja. Nejšn (Nation) smatra da je odgonetnuti značenje iz konteksta jedna od strategija za podučavanje učenika da koriste kontekst koji ukazuje na značenje riječi, te da je ta strategija ključna u nastojanju da se izađe na kraj sa oskudnim vokabularom, posebno prilikom prevođenja originalnih tekstova (Nation, 2001: 232). Blek (Black, 1981) u svom radu iznosi važnost konteksta za razumijevanje metafora te navodi da je kontekst važan da bi se identifikovala i razumjela metafora, kao i to da prepoznavanje i tumačenje metafora mogu zahtijevati obraćanje pažnje na posebne okolnosti metaforičkog izraza (Black, 1981: 29).

Palmer (1976) navodi da postoje jezikoslovci koji, eksplicitno ili implicitno, isključuju kontekst iz proučavanja semantike. On smatra da je razlog taj što postoje velike teorijske i praktične poteškoće u bavljenju kontekstom. Premda se često značenje prikazuje kao nezavisno od konteksta i kao takvo se proučava, postavlja se pitanje kako se može tvrditi da je značenje rečenice moguće znati bez konteksta? Vjerojatno jedino onda kada možemo priložiti drugu rečenicu koja ima slično značenje. On smatra da je očito moguće izmisliti proširenje rečenice kojim možemo objasniti bilo kakvo značenje u vezi s bilo kakvim informacijama koje su važne. Ako je to tako i ako je upotreba takvih proširenja valjana metoda utvrđivanja odnosa smisla, iz toga slijedi da temelj tog odnosa može biti bilo koja informacija i da smisao, kao i referencija, time uključuje cjelokupno ljudsko znanje (Palmer, 1976: 77).

Premda čovjek s lakoćom prepoznaje metaforički jezik, ne oslanjajući se toliko na doslovno značenje, Radman (1995) smatra da treba ponuditi drugi način tumačenja metafore, tj. treba riješiti problem proširenja značenja koje se javlja kod metaforičkih konstrukcija. Postavlja se pitanje kako među svim mogućim konotacijskim značenjima naći ono koje odgovara datoj konstrukciji? Radman navodi da rješenja kao što su ,slobodni prenos naziva ili shema“ ili „slobodno evociranje svakidašnjih izraza“ ne pružaju nikakav jasan kriterij kako ili gdje se zaustaviti pri izboru mogućih značenja, te 
da ,pod pojmom lingvističke kompetencije...treba podrazumijevati proces vaganja relevantnosti potencijalnih značenja datog izraza" (Radman, 1995: 28). Radman smatra da doslovno značenje potpomognuto kontekstom pokazuje pravac metaforičkog značenja, ali se metaforičnost odvija na jednom drugom nivou koji predstavlja posebno semantičko područje šire od domene doslovnog značenja. Ostaje nam da zaključimo da su doslovno i metaforičko značenje međusobno povezani i možda čak i međusobno ovisni.

Na kraju se mora uzeti u obzir da se cijelo značenje metaforičkog izraza ne može uvijek sa sigurnošću utvrditi na osnovu konteksta. Ipak, metaforičke strukture se profiliraju u određenom kontekstu i prevod bi trebao težiti ka vjernosti kontekstu. Kontekst možemo posmatrati kao zbir okolnosti koje objašnjavaju neki dio teksta ili rečenice, bez kojeg nije moguće valjano prevesti neki specifičan izraz. Pogledajmo, na primjer, metaforu to be way up there. Ukoliko se ona prevede bez nepoznavanja rečeničnog konteksta, prevod bi mogao biti u potpunosti pogrešan i mogao bi se protumačiti kao, na primjer, biti na putu prema gore. Međutim, ukoliko ovu istu metaforu sagledamo u rečeničnom kontekstu (npr. His friends all got sick and could not go to the concert. But as to his health, he's way up there), olakšava se prevod koji glasi npr. Svi njegovi prijatelji su se razboljeli i nisu mogli ići na koncert. Ali kada je u pitanju njegovo zdravlje, on je najzdraviji. Svakako je da se upotrebom konteksta dobija jasnija slika o okolnostima koje utiču na prevod, dok se značenje ovakvog ili sličnog metaforičkog izraza može sa većom sigurnošću utvrditi na osnovu konteksta u odnosu na ,izolovanu“ metaforu i neoslanjanje na kontekst, mada to nije pravilo.

\section{Empirijsko istraživanje}

\subsection{Cilj istraživanja $i$ ispitanici}

Predmet ovog istraživanja su glagoli sa metaforičkom dopunom u okviru metaforičkih izraza zdravlja i bolesti iz jezika medicinske struke. Cilj istraživanja je otkriti način na koji su studenti preveli određene meta-

foričke izraze sa engleskog jezika na srpski jezik te da li su se oslanjali na kontekst rečenice ili su ih doslovno prevodili. Konkretno su nas zanimali glagoli sa metaforičkom dopunom orijentacijskih partikula u jeziku medicinske struke. U svrhu postizanja pomenutog cilja sagledali smo prevode 
PREVOĐENJE GLAGOLA SA METAFORIČKOM DOPUNOM

U ENGLESKOM JEZIKU KAO STRANOM

dvadesetoro (20) studenata završne godine filološkog fakulteta. Među ispitanicima je bilo 14 ispitanika ženskog pola i 6 muškog. Uspjeh ispitanika tokom studija je još jedan parametar koji ćemo iskoristiti kako bismo na osnovu njega prikazali uspješnost doslovnih prevoda.

\subsection{Istraživački materijali i metodologija istraživanja}

Materijal koji smo koristili za analizu izdvojili smo iz rječnika sinonima Thesaurus of Traditional English Metaphors (Wilkinson, 2002) i naučnog članka "Conceptual Metaphor in Everyday Language" (Lakoff \& Johnsen, 1980). Cilj nam je bio da pronađemo primjere orijentacijskih metaforičkih izraza koji se odnose na pojmove zdravlja i bolesti iz jezika medicinske struke.

U svrhu postizanja već navedenog cilja sagledali smo prevode studenata, analizirali ih, te smo ih izdvojili manualno i grupisali prema tome da li su ih studenti direktno preveli ili su se koristili prevodom koji se oslanjao na rečenični kontekst. Studenti tek na četvrtoj godini, prema nastavnom planu i programu, dobijaju predmet koji se naziva Engleski jezik struke 1. U okviru pomenutog predmeta obrađuje se medicinska terminologija i metaforičke konstrukcije zdravlja i bolesti. Na osnovu toga smo pretpostavili da se studenti nisu ranije susreli sa pomenutom terminologijom. Očekivalo se da studenti prevedu deset konstrukcija glagola sa metaforičkom dopunom iz domena orijentacijskih metafora. Nisu mogli koristiti rječnik, što bi im vjerovatno predstavljalo olakšicu pri prevođenju. Prevode su radili na redovnom času, te nisu imali vremensko ograničenje za prevod iako su većinom završili zadatak za manje od trideset minuta. Iako je ova analiza urađena na početku semestra, studenti su se prije testiranja prevoda tokom nekoliko prethodnih časova susreli s nekim konstrukcijama iz jezika medicinske struke u okviru predmeta Engleski jezik struke 1. Knjiga koju su koristili je Professional English in Use - Medicine (Glendinning i Howard, 2007) a glagoli sa metaforičkom dopunom iz domena jezika medicinske struke koje su obrađivali u okviru časova su iz knjige English Vocabulary in Use (Advanced) (McCarthy i O'Dell, 2006). Neke od metafora koje su im poznate a koje se mogu pronaći u ovoj knjizi su an ailing organization, a rash of bulgaries, fever pitch, to carry the scars of something, feel under the weather, be over the worst, get back on one's feet (McCarthy i O'Dell, 2006: 129,132).

Od studenta se očekivalo da prevedu sljedećih deset metaforičkih konstrukcija: to be at the peak of health (=,,biti na vrhuncu zdravlja/pu- 
cati od zdravlja“), to sink fast (= ,pogoršati se (zdravstveno stanje))“", to rise from the dead $(=$, ,ozdraviti" $)$, to be way up there (= ,biti zdrav"), to come down with the flu (=,oboljeti od gripe"), his health is declining (= ,zdravlje mu se postepeno pogoršava“"), to drop dead (=,umrijeti" $\left.{ }^{6}\right)$, to take physic before being sick (= ,djelovati preventivno"), to keel over (= „onesvijestiti se $\left.{ }^{6}\right)$, to get back on your feet (= ,oporaviti se)“. Prevod smo grupisali na osnovu toga da li su studenti ponudili direktni prevod (prevod nezavisan od rečeničnog konteksta) ili prevod na osnovu konteksta. Tako, na primjer, pretpostavka je da će studenti gore navedenu metaforu to be at the peak of health lakše prevesti u kontekstu rečenice kao što je npr. From a life cycle perspective, young people were regarded as being at the peak of health, having outgrown the health-related risks of infancy and childhood. Uloga rečeničnog konteksta je da na određen način olakša prevod, mada nije svaki kontekst dovoljno „dobar“ i vjernost njemu ne dovodi uvijek do uspješnog prevoda. Kada se radi o prevodima studenata, napominjemo da je bilo i onih konstrukcija koje su prevedene pogrešno, ali ne i doslovno. Premda su ponuđena samo dva takva prevoda, nismo ih unosili u tabelu. Takođe smo uvrstili i treću kategoriju a to su konstrukcije koje su studenti ostavili neprevedene.

Studenti su trebali prevesti glagole sa metaforičkim konstrukcijama $\mathrm{u}$ kontekstu rečenice. Jedan od primjera je to rise from the dead. Pomenuta konstrukcija je, kao i ostale, prvo izdvojena iznad rečenice zbog preglednosti a zatim je ispod nje navedena ista u rečeničnom kontekstu. Takav kontekst za ovu konstrukciju je He was so sick he thought he would die but three days later he rose from the dead.

\subsection{Rezultati istraživanja $i$ analiza}

Nakon prikupljanja prevoda, unijeli smo ih u tabelu i sortirali kao direktan prevod, prevod na osnovu konteksta i na one konstrukcije koje studenti nisu uopšte preveli. U Tabeli 1 numerički i procentulno ćemo predstaviti koliko je studenata direktno prevelo datu konstrukciju, koliko njih je prevod baziralo na rečeničnom kontekstu a koliko je ostalo neprevedeno. Takođe navodimo neke prevode koje su ponudili studenti. 
PREVOĐENJE GLAGOLA SA METAFORIČKOM DOPUNOM

U ENGLESKOM JEZIKU KAO STRANOM

Tabela 1: Uspješnost prevoda glagola sa metaforičkom dopunom

\begin{tabular}{|l|l|l|l|l|l|l|}
\hline \multirow{2}{*}{ Metaforička konstrukcija } & \multicolumn{2}{|c|}{$\begin{array}{c}\text { Direktni pre- } \\
\text { vod }\end{array}$} & $\begin{array}{c}\text { Uspješan prevod } \\
\text { na osnovu } \\
\text { konteksta }\end{array}$ & \multicolumn{2}{c|}{ Neprevedeno } \\
\cline { 2 - 8 } & $\mathrm{n}$ & $\%$ & $\mathrm{n}$ & $\%$ & $\mathrm{n}$ & $\%$ \\
\hline to be at the peak of health & 5 & 25 & 11 & 55 & 4 & 20 \\
\hline to rise from the dead & 15 & 75 & 1 & 5 & 4 & 20 \\
\hline to be way up there & 6 & 30 & 5 & 25 & 9 & 45 \\
\hline to sink fast & 13 & 65 & 4 & 20 & 3 & 15 \\
\hline to come down with the flu & 12 & 60 & 5 & 25 & 3 & 15 \\
\hline his health is declining & 7 & 35 & 8 & 40 & 5 & 25 \\
\hline to drop dead & 12 & 60 & 4 & 20 & 4 & 20 \\
\hline to take physic before being sick & 5 & 25 & 0 & 0 & 15 & 75 \\
\hline to keel over & 3 & 15 & 10 & 10 & 7 & 35 \\
\hline to get back on your feet & 6 & 30 & 12 & 60 & 2 & 10 \\
\hline UKUPNO & 84 & 42 & 60 & 30 & 56 & 28 \\
\hline
\end{tabular}

Iz tabele vidimo da je ukupan broj direktnih prevoda bio 84, odnosno $42 \%, 60(30 \%)$ prevoda je bilo na osnovu konteksta, dok je neprevedeno bilo ukupno 56 odnoso 28\%. Dakle, studenti su mnoge konstrukcije preveli doslovno (direktnim preslikavanjem pojedinačnih dijelova metaforičkog izraza iz engleskog jezika u srpski).

Međutim, iako je najveći broj prevoda direktni prevod, odnosno doslovni, postavlja se pitanje kakav je to „doslovan prevod“ $i$ šta nam govori da je prevod u kontekstu uspješan. Od studenata smo očekivali da metaforičke konstrukcije prevedu smisleno i u duhu srpskog jezika, te da uzmu u obzir kontekst, kako bi prevod bio definisan kao uspješan prevod u kontekstu. S druge strane, u nekim slučajevima nije potrebno stavljati prevelik naglasak na kontekstualizovani prevod jer doslovan prevod ponekad može u potpunosti odgovarati jeziku cilja. Ovu tvrdnju možemo dokazati i primjerima prevoda pojedinih metaforičkih konstrukcija, koje navodimo u nastavku.

To be at the peak of health: Petoro studenata je ovu konstrukciju prevelo kao biti zdrav kao dren. Ž. Bujas (2005) u svom rječniku ${ }^{3}$ navodi da takav prevod odgovara izrazu to be as fit as a fiddle. Mi smo ipak ovakav prevod klasifikovali kao uspješan jer je značenje odgovarajuće. Drugi prevodi koje su studenti ponudili su on je na vrhu zdravlja te smo takav prevod svakako klasifikovali kao direktan i neodgovarajući. Jedan student

3 Bujas, Ž. 2005. Veliki hrvatsko-engleski rječnik. Zagreb: Nakladni zavod Globus. 
je datu konstrukciju preveo kao osjećati se najbolje što smo klasifikovali kao uspješan prevod. Ostali ponuđeni prevodi su biti na vrhuncu zdravlja i takav prevod je klasifikovan kao uspješan. Iako je ovakav prevod direktno prenesen na jezik cilja, smatramo da je sasvim odgovarajući.

To rise from the dead: Ovu konstrukciju je samo jedan student preveo u kontekstu rečenice kao ozdravio je što se klasifikuje kao uspješan prevod, dok su ostali preveli doslovno pojedinačne riječi i ponudili prevod ustati iz mrtvih. U ovom slučaju, direktan prevod se ne može u potpunosti tretirati kao neodgovarajući, te se mora uzeti u obzir i prenošenje datog metaforičkog izraza odgovarajućom metaforom i u maternjem jeziku, što su u ovom slučaju studenti i uradili, tako da se može zaključiti je navedeni prevod adekvatan u srpskom jeziku.

To be way up there: Većina studenata ovu metaforičku konstrukciju nije ni prevela. Oni koji su je direktno preveli ponudili su prevod ići prema gore, napredovati. Ostali studenti, koji su uspješno ili barem približno uspješno preveli i posmatrali kontekst i prethodnu rečenicu, preveli su je kao on je najzdraviji.

To sink fast: I ovu metaforičku konstrukciju je veliki broj studenta preveo direktno: pacijent tone brzo ili propada brzo. Četvoro studenata je ponudilo prevod zdravlje mu se ubrzano pogoršava; zdravlje mu se pogoršava; bliži mu se smrt te smo takve prevode uvrstili kao uspješne.

His health is declining: Prevod koji je glasio zdravlje joj opada smo klasifikovali kao direktan. Studenti čije smo prevode klasifikovali kao uspješne su dati izraz preveli kao zdravlje joj se pogoršava.

To drop dead: Dvanaestoro studenata je ovo prevelo kao pao je mrtav što smo mi klasifikovali kao direktan prevod jer su ponudili pojedinačan prevod svake riječi. Četvoro studenata je prevelo oslanjajući se na kontekst koji pretpostavlja da određena osoba neće ,pasti mrtva“ ukoliko prestane da uzima tablete. Prevod koji su oni ponudili je umrijeti. Jedan student je ponudio prevod Pao je kao klada, te bi se ovakav prevod mogao svrstati u kategoriju pogrešnog prevoda koji nije doslovan.

To take physic before being sick: Studenti koji su direktno preveli ovu konstrukciju su je prevodili kao uvijek uzima lijekove prije nego što je bolestan. Dvoje je prevelo i kao bolje spriječiti nego liječiti, što je pogrešan prevod, ali ne i doslovan. Čini se kao da se uopšte nisu oslanjali na kontekst rečenice u kojem se pominje i kriminal i policija. Ovo je metaforička konstrukcija koju je najveći broj studenata ostavio neprevedenu. Pretpostavka je da se ranije nisu susreli s pomenutim te da je to razlog neprevođenja. 
Prema gore navedenim primjerima prevoda nekih od ispitanih glagola s metaforičkom dopunom, primjetno je da su parametri za ono što nazivamo „doslovan prevod“ direktno prevođenje pojedinačnih riječi i djelimično ili potpuno zanemarivanje rečeničnog konteksta. Metaforička konstrukcija to get back on one's feet je jedina za koju smo imali saznanje da je od ranije sigurno poznata studentima jer se nalazi u već pomenutom udžbeniku English Vocabulary in Use (Advanced). Ipak, kako se može i vidjeti u tabeli broj 1, dvoje studenata je nije uopšte prevelo a šestoro je ponudilo direktan prevod.

Čini nam se potrebnim pomenuti i opažanje N. Silaški koja preporučuje doslovno prevođenje umjesto parafraziranja ili upotrebe slične metaforičke konstrukcije ukoliko metaforička slika iz izvornog jezika nije lako prevodiva na ciljni (Silaški, 2013: 259). Ponekad doslovno prevođenje ne može prenijeti pravo značenje metaforičkih izraza koji sami po sebi mogu da djeluju zbunjujuće, naročito ne bez oslanjanja na kontekst. S druge strane, neke od navedenih metaforičkih konstrukcija bi bilo teško smisleno prevesti da nije ponuđen nikakav kontekst ali smo isto tako pokazali da je doslovan prevod u nekim slučajevima u potpunosti prihvatljiv.

U tabeli broj 2 predstavićemo broj doslovnih prevoda u odnosu na pol i uspjeh učenika, kako bismo sagledali da li neki od navedenih parametara utiču na direktno preslikavanje glagola sa metaforičkom dopunom u maternji jezik.

Tabela broj 2: Doslovni prevodi u odnosu na pol i uspjeh studenata

\begin{tabular}{|l|c|c|c|c|c|c|c|}
\hline & \multicolumn{3}{|c|}{ Pol } & \multicolumn{5}{c|}{ Uspjeh } \\
\hline Metaforička konstrukcija & Z & $\mathrm{M}$ & 6 & 7 & 8 & 9 & 10 \\
\hline to be at the peak of health & 1 & 4 & 1 & 1 & 3 & 0 & 0 \\
\hline to rise from the dead & 7 & 6 & 0 & 1 & 11 & 1 & 0 \\
\hline to be way up there & 3 & 3 & 3 & 0 & 1 & 2 & 0 \\
\hline to sink fast & 5 & 6 & 0 & 2 & 7 & 2 & 0 \\
\hline to come down with the flue & 6 & 5 & 1 & 2 & 4 & 4 & 0 \\
\hline his health is declining & 2 & 5 & 0 & 2 & 1 & 3 & 1 \\
\hline to drop dead & 4 & 6 & 0 & 2 & 6 & 2 & 0 \\
\hline to take physic before being sick & 2 & 3 & 0 & 2 & 3 & 0 & 0 \\
\hline to keel over & 1 & 2 & 2 & 1 & 0 & 0 & 0 \\
\hline to get back on your feet & 2 & 4 & 0 & 2 & 4 & 0 & 0 \\
\hline
\end{tabular}

Zanimljivo je sagledati stanje doslovnih prevoda kada se sagleda pol učenika. Kako je i vidljivo iz tabele broj 2, uglavnom su veći broj doslovnih 
prevoda ponudili ispitanici muškog pola. Najviše je bilo onih ispitanika sa prosjekom ocjena 8 , tako da je najveći broj doslovnih prevoda i ponuđen od strane tih studenata. Doslovni prevod je ponudio samo jedan student sa prosjekom ocjena 10, i to za metaforičku konstrukciju his health is declining.

S oprezom možemo zaključiti kako su metaforičke konstrukcije koje su studenti doslovno preveli one koje su manje zastupljene u literaturi i s kojima se studenti kroz nastavni plan i program nisu susretali. Manji broj metafora je ostao nepreveden. Iako studenti uče engleski jezik kao strani jezik mnogo godina, jasno je da je i dalje potrebno da samostalno ili u okviru nastavnog procesa razvijaju vještine i kompetencije, proširuju znanje maternjeg i stranog jezika, te da razvijaju metaforičku kompetenciju kao aktivno svjesno poznavanje metafore u svim njenim dimenzijama.

Da ova analiza nije urađena na početku semestra, sigurni smo da bi studenti, koji bi tokom semestra pohađali nastavu i dobijali strukturisani input koji bi se sastojao od vježbi zasnovanih na metaforičkim konstrukcijama i glagolima sa metaforičkom dopunom, mnogo uspješnije preveli date izraze.

\section{Zaključak}

U ovom radu pokušali smo da iznesemo pregled odabranih glagola sa metaforičkom dopunom kao i probleme koji se mogu javiti prilikom prevođenja figurativnog jezika, dok smo u empirijskom dijelu prikazali da li su i kako studenti preveli odabrane glagole sa metaforičkom dopunom iz jezika medicinske struke i koliko se prevod takvih metaforičkih konstrukcija bazirao na upotrebi rečeničnog konteksta.

Iako su mnoge konstrukcije iz odabranog materijala prevodive za studente, pokazalo se da je za studente najčešća i najpopularnija prevodna strategija engleskih metaforičkih termina na srpski jezik ona koja rezultira doslovnim terminom u srpskom jeziku. Svakako bi bilo korisno ovaj zaključak potkrijepiti detaljnijim istraživanjem. Takođe bi bilo zanimljivo istražiti način na koji bi studenti preveli date metaforičke konstrukcije da su mogli koristiti rječnike, te ponoviti ovakvu analizu na kraju semestra, nakon što bi studenti pohađali nastavu i dobijali strukturisani input.

Možemo zaključiti da su u većini slučajeva studenti svjesni međujezičkih razlika ali nisu u mogućnosti da izbjegnu zamke u koje ih može odvesti direktno prevođenje. Međutim, kako je i vidljivo iz primjera prevoda nekih metaforičkih konstrukcija, doslovno prevođenje ne mora uvijek biti pogreš- 
PREVOĐENJE GLAGOLA SA METAFORIČKOM DOPUNOM

U ENGLESKOM JEZIKU KAO STRANOM

no i u nekim slučajevima je direktno preslikavanje pojedinačnih dijelova metaforičkog izraza iz engleskog jezika u srpski u potpunosti odgovarajuće.

Premda su metaforičke konstrukcije koje smo koristili u srpskoj terminologiji kojom se izražavaju pojmovi zdravlja i bolesti još uvijek marginalizovane, moguće je da studentima ne može pomoći ni kontekst jer se nikada ranije nisu susreli s metaforičkim izrazima iz specifičnog jezika medicinske struke.

\section{Literatura}

Andersen, M. S. (2004). Metaforkompetence - en empirisk undersøgelse af semi-professionelle overscetteres metaforviden. Copenhagen: Copenhagen Working Papers in LSP.

Babel, K. (2012). Metafore zdravlja i bolesti u medicinskoj praksi. Filozofska istraživanja, 32, 121-138.

Black, M. 1981. Models and Metaphors - Studies in Language and Philosophy. New York: Cornell University Press.

Clow, B. (2001). Who's Afraid of Susan Sontag?. Social History of Medicine, 14 (2), 293-312.

Dobrzynska, T. 1995. Translating metaphor: problems of meaning. Journal of Pragmatics 24 (6), 597-603.

Fernandez, S. E. (2002) Translators' English-Spanish metaphorical competence: impact on the target system. Estudios de lingüistica inglesa aplicada (ELIA), 3, 203-218.

Huijbrechts, O. (2016). Metaphor and illness experience: A comparative analysis of metaphors in male and female cancer patient narratives. Unpublished MA thesis, Leiden University.

Klikovac, D. (2004). Metafore u mišljenju i jeziku. Beograd: Biblioteka XX vek: Knjižara Krug.

Kövecses, Z. (2010). Metaphor: A Practical Introduction. Oxford: Oxford University Press.

Lakoff, G. and Johnsen, M. (1980). Conceptual Metaphor in Everyday Language. The Journal of Philosophy, 77 (8), 453-486.

Lakoff, G. and Johnsen, M. (2003). Metaphors We Live By. Chicago: University of Chicago Press.

Nation P. (2001). Learning Vocabulary in Another Language, London: Cambridge University Press.

Palmer, R. F. (1976). Semantics: a new outline. Cambridge: Cambridge University Press. 
Radić-Bojanić, B. (2014). Uloga maternjeg jezika u razumevanju metaforičkog vokabulara engleskog jezika kao stranog. Filologija i univerzitet (707718). Niš: Filozofski fakultet Univerzitet u Nišu.

Radman, Z. (1995). Metafore i mehanizmi mišljenja. Zagreb: Hrvatsko filozofsko društvo.

Silaški, N. (2013). Zašto ekonomisti (ne) vole metafore? Tradicija i inovacije $u$ savremenom srpskom jeziku (255-265). Kragujevac: FILUM.

Schäffner, C. (2004). Metaphor and translation: some implications of a cognitive approach, Journal of Pragmatics, 36, 1253-1269.

Schmidt, G. (2014). Metaphor translation in subtitling. Journal of Foreign Language Teaching and Applied Linguistics, 2, 95-104.

Sontag, S. (1978). Illness as Metaphor. New York: Farrar, Strauss \& Giroux.

Sjørup, A. C. (2013). Cognitive effort in metaphor translation: An eye-tracking and key-logging study. Frederiksberg: Copenhagen Business School.

Wilkinson, P.R. (2002). Thesaurus of Traditional English Metaphors. New York: Routledge.

Mihaela M. Malešević

\section{Summary}

\section{TRANSLATION OF VERBS WITH A METAPHORICAL COMPLEMENT IN ENGLISH AS A FOREIGN LANGUAGE}

The aim of the paper is to analyze the successfulness of literal translations of selected verbs with metaphorical complements and translations of such metaphorical constructs based on the use of context, in the language of medicine.

In the theoretical part of the paper we provide an overview of conceptual metaphors as well as the problems that may occur when translating the figurative language, while in the empirical part we will show how the students that for the first time, according to the curriculum, meet such constructions, translate the given verbs with the metaphorical supplement and to what extent they rely on the context of the sentence. The analysis is based on the translation of ten verbs and metaphors of health and disease from the dictionary of synonyms Thesaurus of Traditional English Metaphors and scientific paper "Conceptual Metaphor in Everyday Language".

Key words: English language, the language of medicine, context and translation, metaphorical complement 